\title{
The effect of replacement of rice in a poor vegetarian diet by tapioca macaroni on the general health and nutritional status of children
}

\author{
BY V. SUBRAHMANYAN, R. K. BHAGAWAN, T. R. DORAISWAMY, \\ KANTHA JOSEPH, G. S. BAINS, D. S. BHATIA, A. N. SANKARAN \\ AND M. SWAMINATHAN \\ Central Food Technological Research Institute, Mysore, India
}

(Received 25 Fanuary 1958-Revised I5 April 1958)

One of the most important food problems of India and many other east and south-east Asian countries, in general, is the provision of adequate amounts of cereals in the diet to meet the caloric requirements of the people. The total production of food grains has been steadily increasing as a result of improved methods of agriculture, but the demand from the rapidly growing population has also correspondingly increased. As a result, the estimated per capita national cereal supplies have remained more or less static (Food and Agriculture Organization of the United Nations, 1956). Countries like India continue to import food grains.

In certain countries, such as Japan, the Philippines and Indonesia, efforts have been made to make up the caloric deficit by increasing the production and consumption of high-yielding tuber crops like sweet potato and tapioca (Manihot utilissima). The average per capita consumption of roots and tubers in these countries has been estimated to be now well over 5-6 oz./day (Food and Agriculture Organization of the United Nations, 1956). A suggestion for meeting the food deficit in India by the use of a blend of tapioca flour and groundnut flour was made by Subrahmanyan, Doraiswamy, Swaminathan \& Sankaran (1953-4). It must be mentioned, however, that flour, though readily acceptable to wheat- and millet-eaters, is disliked by rice-eaters who are accustomed to eating rice in the form of cooked grains. Provision of a substitute for rice has therefore become one of the major food problems, not only for India but also for all Asian regions where rice is eaten.

In a previous publication from this laboratory, Subrahmanyan, Bhatia, Swaminathan \& Bains (1954) reported that rice-shaped grains with a chemical composition similar to that of natural rice could be manufactured from a blend of tapioca flour, groundnut flour and semolina. This product, originally called 'synthetic rice', has more recently been named tapioca macaroni as the process is essentially similar to that followed in the manufacture of macaroni products from semolina (Hummel, I950). Besides 'synthetic rice', other shapes such as shells, tubes, sago-like granules and vermicelli can also be made from the same blend on a commercial macaroni press by using different dies. More recently, the production of tapioca macaroni on a pilot-plant scale has been carried out in this Institute, with a view to finding out the acceptability 
of the product and assessing its nutritive value as a substitute for rice in the diet of children. The manufacture of similar products, based on a blend of wheat flour and potato starch has been reported from Japan (Dodson, 1954).

Subrahmanyan, Bains, Swaminathan \& Bhatia (1954-5) reported that a poor vegetarian diet based on tapioca macaroni prepared by the method of Subrahmanyan et al. (I954) promoted significantly higher rates of growth in albino rats than a similar diet based on raw milled rice. The present paper deals with studies on the effect of replacing rice in a poor vegetarian diet by tapioca macaroni on the growth, general health and nutritional status of schoolchildren.

\section{EXPERIMENTAL}

Rice-shaped tapioca macaroni was prepared on a pilot-plant scale from a blend of tapioca flour (6o parts), low-fat groundnut flour ( $5_{5}$ parts), and wheat semolina (25 parts), by the process described earlier (Subrahmanyan et al. 1954).

Chemical composition. The composition of uncooked tapioca macaroni as compared with that of raw milled rice is given in Table $\mathrm{I}$. The proximate principles and minerals were estimated by the methods of the Association of Official Agricultural Chemists (1950). Thiamine and nicotinic acid were determined by the method of Swaminathan $(1942 a, b)$ and riboflavin by that of the American Association of Vitamin Chemists (1951).

Table I. Chemical composition of tapioca macaroni compared with that of raw milled rice

\begin{tabular}{lcc}
\multicolumn{1}{c}{$\begin{array}{c}\text { Constituent } \\
\text { (Values/100 g) }\end{array}$} & $\begin{array}{c}\text { Tapioca } \\
\text { macaroni }\end{array}$ & $\begin{array}{c}\text { Raw milled } \\
\text { rice }\end{array}$ \\
Moisture (g) & 10.8 & \\
Fibre (g) & 0.6 & 12.1 \\
Ash (g) & $1 \cdot 9$ & 0.2 \\
Protein (N $\times 6.25)(\mathrm{g})$ & $11 \cdot 3$ & 0.5 \\
Fat (g) & 1.8 & 6.8 \\
Carbohydrate (by difference) (g) & 73.6 & 0.4 \\
Calcium (mg) & 53.5 & 10.0 \\
Phosphorus (mg) & 144.6 & 132.5 \\
Iron (mg) & 3.0 & 1.2 \\
Thiamine (mg) & 0.21 & 0.12 \\
Nicotinic acid (mg) & 3.6 & 1.3 \\
Riboflavin (mg) & 0.07 & 0.02
\end{tabular}

Cooking of tapioca macaroni. Tapioca macaroni can be cooked in the same way as rice. The time required for cooking, however, is only $6-7 \mathrm{~min}$ as compared with 20-25 min required for cooking natural rice. The method of cooking used in the feeding experiments was: $8 \mathrm{lb}$. tapioca macaroni were added to 4 gal. boiling water. The mixture was boiled for $6-7$ min with occasional stirring. The excess gruel was drained off through a sieve. The cooked macaroni as well as the gruel were given to the subjects along with the rest of the diet. Raw milled rice was cooked (for about $20 \mathrm{~min}$ ) in the above manner to the proper consistency and both the rice gruel and the cooked rice were consumed by the children.

Subjects. A boarding home housing sixty girls of ages ranging from 4 to 15 years, 
was selected for the investigation. All the girls below 12 years were examined clinically. Thirty-two girls aged between 4 and I I years and free from diseases likely to interfere with the experiment were selected as experimental subjects. All the children were treated for worms by the administration of santonin 3 weeks before the beginning of the experiment.

Physical measurements, assessment of nutritional status and selection of subjects. Height, weight, nutritional status, red blood cell count and haemoglobin content of the blood of the subjects were recorded. Height was measured to the nearest $\frac{1}{8}$ in. and weight to the nearest $\frac{1}{8} \mathrm{lb}$. Nutritional status was assessed according to the score-card worked out by the Indian Council of Medical Research: Nutrition Advisory Committee (1948). Haemoglobin was determined by the acid-haematin method with a Sahli-Hellige haemometer (Hepler, 1950) and the red blood cell count was made by standard methods with Neubauer's haemocytometer. On the basis of the initial height, weight and nutritional status, the children were paired and the members of each pair were allotted at random to one of two groups of sixteen, one receiving tapioca macaroni and the other rice.

Composition of experimental diets and feeding of children. A diet survey was conducted according to the procedure described in an earlier paper (Reddy, Doraiswamy, Sankaran, Swaminathan \& Subrahmanyan, 1954). The pattern of the diets taken by the two groups is given in Table 2. The nutritive value of the diets, calculated from

Table 2. Pattern of the diets consumed by the children

\begin{tabular}{lr} 
& \multicolumn{2}{c}{$\begin{array}{c}\text { Daily } \\
\text { intake/child } \\
\text { Foodstuff }\end{array}$} \\
Control group (rice diet) & $225 \cdot 0$ \\
Rice, raw milled & $225 \cdot 0$ \\
Experimental group (tapioca-macaroni diet) & $16 \cdot 8$ \\
Tapioca macaroni & $25 \cdot 8$ \\
Both groups & \\
White bread & $44 \cdot 5$ \\
Pulses (Bengal-gram dhal (Cicer arietinum) and horse-gram (Dolichos biflorus) & $3 \cdot 7$ \\
Vegetables (amaranthus, tender; radish tops; radish white; drumsticks; cho-cho & $2 \cdot 5$ \\
marrow; tomato, green; potato) & $18 \cdot 2$ \\
Condiments (chillies, red, dry; garlic; cumin; coriander seeds; mustard; turmeric) & $3 \cdot 7$ \\
Tamarind fruit pulp & $2 \cdot 0$ \\
Jaggery & $2 \cdot 8$ \\
Onion & $10 \cdot 0$ \\
American butter oil & $6 \cdot 3$ \\
Skim-milk powder &
\end{tabular}

The mean consumption unit for both groups was 0.8 and was calculated from the international scale of family coefficients (League of Nations Health Organization, 1932).

the values given by Aykroyd, Patwardhan \& Ranganathan (1951) is shown in Table 3 and compared with the dietary requirements of children of similar age groups suggested by the Indian Council of Medical Research: Nutrition Advisory Committee (1944). The subjects were fed three times a day. The pattern of breakfast, lunch and dinner was similar to that described by Reddy et al. (1954). All the children relished 
the tapioca-macaroni preparations. None complained of any digestive trouble during the experimental period. The experiment was begun in June 1957 and lasted for 6 months, at the end of which the height, weight, nutritional status, red blood cell count and haemoglobin content were again assessed.

Table 3. Mean daily intake of different nutrients by the children

$\begin{array}{lccc}\quad \begin{array}{c}\text { Nutrient } \\ \text { group } \\ \text { (rice diet) }\end{array} & \begin{array}{c}\text { Experimental } \\ \text { group (tapioca- } \\ \text { macaroni diet) }\end{array} & \begin{array}{c}\text { N.A.c. } \\ \text { standard* }\end{array} \\ \text { Calories (Cal.) } & \text { I I 20 } & \text { 1 } 130 & 2000 \\ \text { Protein (g) } & 29.6 & 39.7 & 57 \\ \text { Fat (g) } & 6.2 & 9.4 & - \\ \text { Carbohydrate (g) } & 238 & 223 & - \\ \text { Calcium (g) } & 0.29 & 0.39 & 1-1.5 \\ \text { Phosphorus (g) } & 0.56 & 0.59 & - \\ \text { Iron (mg) } & 9.5 & 13.6 & 10-30 \\ \text { Vitamin A: } & & & \\ \quad \text { As vitamin A (i.u.) } & 83.0 & 83.0 & 3000-4000 \\ \text { As carotene (i.u.) } & 885.0 & 885.0 & \\ \text { Thiamine (mg) } & 0.46 & 0.66 & 0.5-1 \\ \text { Riboflavin (mg) } & 0.38 & 0.49 & 1.8 \dagger \\ \text { Nicotinic acid (mg) } & 5.7 & 10.9 & 12.0 \dagger \\ \text { Ascorbic acid (mg) } & 24.6 & 24.6 & 30-50\end{array}$

* Recommendations of the Indian Council of Medical Research: Nutrition Advisory Committee (1944).

$\dagger$ Recommendations of the (U.S.A.) National Research Council: Food and Nutrition Board (I948).

\section{RESULTS}

Table 4 shows the initial and final values for the different measurements. It will be seen that at the beginning of the experiment the two groups of subjects were closely similar. For the purpose of statistical analysis the increase in the various measurements during the experimental period was obtained for each subject: from these measurements the mean increase was obtained for each group. The differences in the mean

Table 4. Mean values for the initial and final measurements of the children in the controi (rice diet) and experimental (tapioca-macaroni diet) groups

\begin{tabular}{|c|c|c|c|c|c|c|c|}
\hline \multicolumn{8}{|c|}{ (Sixteen children/group) } \\
\hline & \multicolumn{3}{|c|}{ Control group (a) } & \multicolumn{3}{|c|}{ Experimental group (b) } & \multirow{2}{*}{$\begin{array}{l}\text { Difference in } \\
\text { increase }(b-a)\end{array}$} \\
\hline Measurement & Initial & Final & Increase & Initial & Final & Increase & \\
\hline Height (in.) & $46 \cdot 56$ & $47 \cdot 17$ & 0.61 & $46 \cdot 85$ & $47 \cdot 47$ & 0.62 & $+0.01 \pm 0.08$ \\
\hline Weight (lb.) & $42 \cdot 19$ & $44^{\circ} 02$ & $x \cdot 83$ & $42 \cdot 42$ & $44 \cdot 36$ & $x \cdot 94$ & $+0.1 x \pm 0.73$ \\
\hline Haemoglobin (g/100 ml.) & $12 \cdot 14$ & $x+97$ & -0.17 & I $x \cdot 86$ & II.99 & 0.13 & $+0.30 \pm 0.11 *$ \\
\hline Red blood cell count & $4 \cdot 28$ & $4 \cdot 45$ & 0.17 & $4: 32$ & $4 \cdot 44$ & 0.12 & $-0.05 \pm 0.08$ \\
\hline
\end{tabular}
$\left(10^{6} / \mathrm{mm}^{3}\right)$

Standard error of the mean based on 15 degrees of freedom.

* Significant at $P=0.02$.

increase between the two groups were tested by the $t$ test appropriate for paired comparisons. The results of the statistical analysis are also presented in Table 4 . It will be seen that the mean increase in height in the two groups was almost the same. The increase in weight in the experimental group was slightly greater than that observed 
in the control group, the difference, however, was not significant. A small but significant difference in favour of the tapioca-macaroni group was noted in the increase in the haemoglobin content. It so happened that the control group had a distinctly higher initial haemoglobin content than the experimental group. The results given in Table 5 indicate that improvement in nutritional status may have occurred more often in the group given tapioca macaroni than in that given the rice diet.

Table 5. Nutritional status of children in the control (rice diet) and experimental (tapioca-macaroni diet) groups

\begin{tabular}{|c|c|c|c|c|c|c|c|c|}
\hline \multirow[b]{4}{*}{$\begin{array}{l}\text { Nutritional } \\
\text { score* }\end{array}$} & \multirow{2}{*}{\multicolumn{2}{|c|}{$\begin{array}{l}\text { Initial nutritional } \\
\text { status of children }\end{array}$}} & \multicolumn{6}{|c|}{ Changes in the nutritional status of children } \\
\hline & & & \multirow{2}{*}{\multicolumn{3}{|c|}{$\begin{array}{l}\text { Control group, } \\
\text { no. of children }\end{array}$}} & \multirow{2}{*}{\multicolumn{3}{|c|}{$\begin{array}{l}\text { Experimental group, } \\
\text { no. of children }\end{array}$}} \\
\hline & Control & Experimental & & & & & & \\
\hline & $\begin{array}{l}\text { group, } \\
\text { no. of children }\end{array}$ & $\begin{array}{l}\text { group, } \\
\text { no. of children }\end{array}$ & Improved & $\begin{array}{l}\text { Sta- } \\
\text { tionary }\end{array}$ & $\begin{array}{l}\text { Deterio- } \\
\text { rated }\end{array}$ & Improved & $\begin{array}{l}\text { Stan } \\
\text { tionary }\end{array}$ & $\begin{array}{l}\text { Deterio- } \\
\text { rated }\end{array}$ \\
\hline$\circ$ & $\circ$ & 2 & - & - & $\ldots$ & - & 2 & - \\
\hline $\mathbf{I}$ & 3 & I & I & 2 & 一 & I & - & - \\
\hline 2 & 6 & 3 & I & 5 & - & 2 & $\mathbf{I}$ & - \\
\hline 3 & 2 & 7 & - & I & $\mathbf{I}$ & 2 & 5 & 一 \\
\hline 4 & 2 & 2 & I & I & - & 2 & - & - \\
\hline 5 & 3 & - & - & 2 & I & - & - & - \\
\hline 6 & - & - & - & - & - & - & - & - \\
\hline 7 & - & 一 & - & $\ldots$ & $\ldots$ & $\ldots$ & $\ldots$ & - \\
\hline 8 & - & I & - & 一 & 一 & - & I & - \\
\hline Total & 16 & 16 & 3 & I I & 2 & 7 & 9 & - \\
\hline
\end{tabular}

DISCUSSION

Our investigation has shown that ( 1 ) tapioca macaroni was acceptable as a substitute for rice to children who were habitual rice-eaters, and (2) consumption of tapioca macaroni in place of rice over a period of 6 months did not cause any change in the growth of the children. Large-scale consumer acceptability trials conducted by workers in this Institute have shown that food preparations from tapioca macaroni are highly acceptable to rice-eaters in South India. It will thus be seen that tapioca macaroni offers great scope for making up the rice shortage in Asian countries. The main advantages of its use are ( $\mathrm{I}$ ) tapioca, which forms the main ingredient; yields about two or three times as many calories/acre as cereal crops; (2) groundnut meal used as a source of protein is plentiful in India at a low cost as a by-product of the oil industry; and (3) the cost of the finished product is expected to be less than that of natural rice. It has the added advantage that its nutritive value can be easily improved at a slight extra cost by fortification with calcium, thiamine and riboflavin - the nutrients in which rice diets are very deficient (Aykroyd, Krishnan, Passmore \& Sundararajan, 1940).

\section{SUMMARY}

I. A feeding experiment extending over a period of 6 months was carried out on thirty-two girls aged $4^{-\mathrm{I}}$ I years in a boarding home in Mysore to assess the effect of replacing rice in a poor vegetarian diet by tapioca macaroni composed of tapioca flour 
(60 parts), low-fat groundnut flour (I 5 parts) and wheat semolina (25 parts) on the growth, general health and nutritional status of children.

2. The children were paired according to initial height and weight and the members of each pair allotted at random to the rice and tapioca-macaroni groups.

3. Values for weight, height, nutritional status, haemoglobin level and red blood cell count were obtained at the beginning and end of the experiment for the subjects in the control and experimental groups.

4. There was no significant difference in the increase in weight, height, and red-cell count between the two groups.

5. Seven children in the tapioca-macaroni group improved in nutritional status as compared with three children in the rice group. Further, two children in the rice group showed deterioration in the nutritional status, but none in the tapioca-macaroni group showed any deterioration.

Our thanks are due to the authorities of the Good Shepherd Convent, Mysore, for providing facilities for conducting the experiment and to Miss K. Indiramma for help in the statistical analysis of the results.

\section{REFERENCES}

American Association of Vitamin Chemists (I95I). Methods of Vitamin Assay, 2nd ed. New York: Interscience Publishers, Inc.

Association of Official Agricultural Chemists (1950). Official and Tentative Methods of Analysis, 7 th ed. Washington: Association of Official Agricultural Chemists.

Aykroyd, W. R., Krishnan, B. G., Passmore, R. \& Sundararajan, A. R. (1940). Indian med. Res. Mem. no. 32 .

Aykroyd, W. R., Patwardhan, V. N. \& Ranganathan, S. (I95I). The Nutritive Value of Indian Foods and the Planning of Satisfactory Diets, 4 th ed. Delhi: Manager of Publications.

Dodson, J. C. (1954). Rice, F. 57, no. 2, 2 r.

Food and Agriculture Organization of the United Nations (1956). Yearb. Fd agric. Statist. ro, part I.

Hepler, O. E. (I950). Manual of Clinical Laboratory Methods, 4th ed. Springfield, Ill.: C. C. Thomas.

Hummel, C. (1950). Macaroni Products, ist ed. London: Food Trade Press Ltd.

Indian Council of Medical Research: Nutrition Advisory Committee (1944). Report of the Scientific Advisory Board for the year 1944. New Delhi: Indian Council of Medical Research.

Indian Council of Medical Research: Nutrition Advisory Committee (1948). Report of the Scientific Advisory Board for the year 1948. New Delhi: Indian Council of Medical Research.

League of Nations Health Organization (1932). Quart. Bull. Hlth Org. L. o. N. r, 479.

National Research Council: Food and Nutrition Board (1948). Repr. nat. Res. Coun., Wash., no. I 29.

Reddy, S. K., Doraiswamy, T. R., Sankaran, A. N., Swaminathan, M. \& Subrahmanyan, V. (I954). Brit. F. Nutr. 8, 17.

Subrahmanyan, V., Bains, G. S., Swaminathan, M. \& Bhatia, D. S. (1954-5). Bull. cent. Fd tech. Res. Inst. 4,55 .

Subrahmanyan, V., Bhatia, D. S., Swaminathan, M. \& Bains, G. S. (1954). Nature, Lond., 174, 199.

Subrahmanyan, V., Doraiswamy, T. R., Swaminathan, M. \& Sankaran, A. N. (1953-4). Bull. cent. Fd tech. Res. Inst. 3, 267.

Swaminathan, M. (I942a). Indian F. med. Res. 30, 263.

Swaminathan, M. (1942b). Indian F. med. Res. 30, 397. 